\title{
THE PLACE OF PAST EVENTS IN INTERNATIONAL INFORMATION WARS ${ }^{1}$
}

\author{
Alvydas Nikžentaitis \\ (Lithuanian Institute of History)
}

\begin{abstract}
This article presents an analysis of the role memory culture plays in information wars. Based on the examples of Lithuania, Russia, Ukraine, Poland and Belarus, it finds that the phenomenon of using the past in information wars can be explained as a fighting measure to entrench the authority of a given country in the eyes of the global community. This requirement emerged among countries in this region following the collapse of the old global systems and with the creation of new political blocs. Associations have been noticed between information wars that exploit the past and the growth of a country's economic potential. For this reason, this foreign policy tool has not been used to the same degree in different countries in the region, nor did it start being used at the same time. Almost all the countries in the region started to massively exploit the past as a means of soft power only in the 21st century. This tool is especially significant in Poland and Russia, being used less often in Lithuania and Ukraine, and hardly at all in Belarus. The storylines of the past being used in information wars can be divided into two categories: Global identities, whose symbols have become Holocaust and Gulag figures; and symbols associated with the memory cultures and identities of separate societies, such as the idea of Slavic unity (in Russian-Ukrainian relations) or the past of the Grand Duchy of Lithuania (in Lithuanian-Belarusian relations). The author predicts that the use of the past in information wars is set to intensify in the future, and as such, the teaching of expert skills is necessary to address this; at present, these skills are lacking in countries in the region.
\end{abstract}

KEYWORDS: information wars; memory cultures; history policy; Lithuania; Russia; Ukraine; Belarus; Poland.

An analysis of the problem should begin from the thesis that information wars are not a new phenomenon. They can be dated to the first appearance of human civilisation. The various contexts of

${ }^{1}$ The research 'Identity Modernisation? “Europeanisation”, Nationalism and PostSoviet Challenges on Memory Cultures' was financed by the Research Council of Lithuania (No MOD-17006). 
these earlier wars have also come to the attention of Lithuanian researchers. ${ }^{2}$ On the other hand, we cannot ignore the fact that until the beginning of the 21st century, these information wars were often only local. They did not play a particularly important role in interstate relations. We can speculate on how this might have happened. There are several versions:

1) From the second half of the 2oth century, and especially from the end of the century, the concept of foreign policy became significantly broader. States started paying much more attention not only to realpolitik, but also to the accumulation of symbolic capital. It is perhaps no coincidence that precisely from the $198 \mathrm{os}$, when analysing international relations in political science, the theory of constructivism started being used quite productively. It tries to explain interstate relations not only through rational acts, but draws attention to how soft technologies or subjective phenomena such as stereotypes influence relations between states. ${ }^{3}$

2) The borders between domestic and foreign policy have been erased.

3) The world order has changed. The formation of major political and military blocs in the world, and the way they have incorporated smaller states, has meant that the latter seek support from other members of the bloc, demand solidarity, and have even initiated or turned relations into information wars in the region. In other words, the circle of subjects who are able to initiate such conflicts has widened.

4) This has been influenced by new means of spreading information, first of all the spread of the Internet, which has accelerated the distribution of information considerably. ${ }^{4}$

${ }^{2}$ N. Maliukevičius, 'Ekspansijos iš Rytų apraraiškos Lietuvos informacinëje erdvėje', Politologija, 2 (2006); N. Maliukevičius, Rusijos informacijos geopolitikos potencialas ir sklaida Lietuvoje (Vilnius, 2008); V. Savukynas, 'Informaciniai karai kultūros semiotikos požiūriu (taikinys - tapatumas)', Agora. Politiniu komunikaciju studijos, 2 (12), (2013), pp. 42-6o; R. Misiūnas, Informaciniu kovu kryžkelèse: JAV lietuviu informacines kovos XIX a. pab. - $1922 \mathrm{~m}$. (Vilnius, 2004).

${ }^{3} \mathrm{Cf}$. Ch. Weller, 'Internationale Politik und Konstruktivismus. Ein Beipackzettel', WeltTrends, 41, Winter 2003/2004, pp. 107-123, here: pp. 107, 109.

${ }^{4}$ See: A. Erll, Kollektives Gedächtnis und Erinnerungskulturen: Eine Einführung (Weimar, 2011). 
5) The world is experiencing a crisis of values, at least from the end of the 2oth century. On one hand, from the late 2oth century, a consensus formed in the Western world on condemnation of the Holocaust, as a moral and identity-forming factor uniting the Western community. ${ }^{5}$ On the other hand, the aspirations of new members of the Western community to give the same meaning to the Gulag has only resulted in competition ${ }^{6}$ within the community. At the same time, mistrust in values has increased all over the world, and new national identities have rapidly formed. Once the borders between domestic and foreign policy disappeared, the elements of these new identities, especially if some of them clash with the values of other countries, have led to identity conflicts, at the core of which have been assessments of the past. These types of conflict are what make up the essence of information wars.

What kind of past ends up at the epicentre of information wars? I shall try to answer this question by using examples from Lithuania and neighbouring countries. First of all, identity conflicts arise in the international space as the balance of power in the world changes. The cases of Poland and Russia best illustrate this case.

We could say that immediately after the collapse of the Soviet Union, Russia hardly engaged in active history politics; therefore, it did not participate in information wars with the past at the centre. Everything changed after 2000. High oil prices and conjunctures favourable to Russian business meant that Russia ceased being dependent on assistance from the West. Over a rather short period of time, it managed to repay its foreign debt, and accumulated relatively large financial reserves. Its economy grew for over a decade, as did the welfare of its population. ${ }^{7}$ In this situation, more than ever, Russia's new elites were faced with the question of international recognition.

${ }^{5}$ A. Smolar, 'Geschichtspolitik in Polen', Transit, 35 (2008), pp. 50-67.

${ }^{6}$ H. Rousso, 'Dilemma eines europäischen Gedächtnisses', Zeithistorische Forschungen/Studies in Contemporary History, Online-Ausgabe, 1 (2004), H. 3, http:// www.zeithistorische-forschungen.de/16126o41-Rousso-3-2004 (accessed: 2019-o9-30).

${ }^{7}$ Р. Пихоя, Москва, Кремль, власть: Россия на изломе тысячелетий, 19852005. Две истории одной страны (Москва, 2007), pp. 520-521. 
Regardless of the ambivalent attitude towards history among most of the Russian elite, they proposed a clear goal for themselves: for the international community to view Russia as a superstate. Even though it could easily claim this status based only on its size and resources, it is having a hard time convincing other major states of this fact, primarily because of the weakness of its state symbols. The lack of symbolic power contributed significantly to the fact that very strong grievances have formed within Russian society. This feeling has probably developed into a complex, becoming a critical factor in domestic and foreign policy. Russia's grievances are made up of numerous components: its devaluation as an important foreign policy partner, ignorance of its actual or alleged interests in the 'near abroad' or post-Soviet space, etc.

In this context, at the beginning of the 21st century, a new aim arose to establish Russia's attitude towards the Russian and Soviet past in the international arena. In order to realise this, new instruments were created for the implementation of history politics. Russia did not take the same steps as other post-communist countries had, and did not establish a national memory institute, as a number of experts recommended in 2003, but chose a somewhat more complicated but in hindsight more effective route. Instead of one institution, a whole range of organisations were established that did not become state structures, but had the financial and logistical backing of the Russian government. In order to realise its aims in history policy, in 2005, Evopa publishers was created in Russia, followed by the Regnum information agency in 2006, the Historical Memory ${ }^{8}$ and Historical Perspective foundations in 2004, and numerous Internet portals. ${ }^{9}$ The year 2005 was a real turning point in the formation of active Russian history policy in terms of its neighbours. From this point on, it was no longer just those who had other beliefs in Russia that became a target, but foreign countries as well.

${ }^{8}$ М. Колеров, “Историческая политика' в современной России: поиск институтов и языка', Русский сборник. Исследования по истории России, 16 (2014), pp. 441-48o, here: pp. 469-473.

${ }^{9}$ A. Becker, Mythos Stalin. Stalinismus und staatliche Geschichtspolitik im postsowjetischen Russland der Ära Putin (Berlin-Brandenburg, 2016), pp. 73-75. 
In that year, enormous ceremonies were organised in Russia, to which the heads of numerous countries in the world were invited. The commemoration of 9 May in Moscow was meant to show the whole world and society that Russia was a great state, respected all around the world. Vladimir Putin viewed the refusal of the presidents of Estonia, Lithuania and Ukraine to attend the ceremonies as an insult to him personally, and to Russia. Two years later, in 2007, when Estonia moved the Bronze Soldier monument, ${ }^{10}$ the decision was taken in Russia to implement active history policy measures against people and organisations living in foreign countries. A law started being drafted in Russia in 2008 which foresaw criminal prosecution for denying or condemning the Soviet Union's stance against Hitler's Germany. The nature of the law being so oriented towards its 'near abroad' was evident in the provision written in the initial draft of the law, which said that the law had to apply in the former Soviet Union, as defined by its 22 July 1941 borders." A draft law of this kind alone testified to how challenging it was for Russia's political elites to come to terms with post-Cold War situation.

In the sense of policy on the past, the end of the Cold War signalled the end of two dominant narratives about the Second World War. During the Cold War, the Western and Soviet narratives were quite similar. Then a third one emerged, the East and Central European one; and possibly even a fourth, the German. Attempts to see that the Russian version was internationally recognised, and the international opposition to this move, first of all from the Baltic States and Poland, played an important part in the emergence of a new phenomenon in the region, memory (information) wars. The different perception of the role of the Red Army in Poland and the Baltic States brought down and continues to bring down two fundamental pillars of Russian memory policy:

1) the importance of the victory over Nazism, which was denied; and

${ }^{10} \mathrm{~K}$. Brügemann, 'Denkmäler des Grolls. Estland und die Kriege des 20. Jahrhunderts', Osteuropa, 58, H. 6 (2008), pp. 129-146.

${ }^{11}$ Н. Копосов, Память строгого режима. История и политика в России (Москва, 2011), pp. 229-231. 
2) the Soviet army as the liberator of Europe being called a myth. Assessments of the Second World War in neighbouring countries are often generalised, adding the postwar period to these interpretations. In this way, the history of the Second World War becomes a struggle between good (democracy) and evil (Soviet [Russian] despotism). Russia finds this unacceptable, as the Great Patriotic War is one of the most important resources in its symbolic imagination as a great state. ${ }^{12}$

Precisely for these reasons, in 2009 a decree from President Dmitri Medvedev established a commission against falsificators of the past. ${ }^{13}$ This was also a response to the ESBO resolution passed that same year in Vilnius which condemned Nazism and Stalinism. ${ }^{14}$ The creation of this commission was a logical reaction, as the document clashed with the Russian history policy aims that Vladimir Putin formulated in his 2007 meeting with humanities lecturers:

1) History must be taught in a way that encourages feelings of national pride; and

2) Russia will not allow itself to be made to feel guilty. ${ }^{15}$

The commission was abolished in 2012. Unlike the resolution about its establishment, its closure was hardly noticed in mass information channels. Direct assessments of its activities noted a more

${ }^{12}$ И. Торбаков, “Непредсказуемое' или 'неопределенное' прошлое? Международные отношения и российская историческая политика', in: Символическая политика. Выпуск 1: Конструирование представлений о прошлом как властный ресурс, (ed.) Ольга Малинова, Вып. 1 (Москва, 2013), pp. 91-125; here: pp. 103-106.

${ }^{13}$ 'Russland kämpft. Gesetz und Kommission gegen Geschichtsfälscher',Osteuropa, Jg. 59, H. 7-8 (2009), pp. 273-276; G. Michaleva, 'Vergangenheitsbewältigung als Voraussetzung für die Modernisierung Russlands', Ibid., pp. 47-58, here: pp. $5^{6-}$ 57. For more about the memory wars between Russia and the Baltic States, see: E. Zubkova, 'Sowjetische Vergangenheit der baltischen Staaten: Schwerpunkte und Kontroverse der kollektiven Erinnerung und Geschichtsschreibung', Geschichtspolitik im erweiterten Ostseeraum und ihre aktuellen Symptome - Historical Memory Culture in the Enlarged Baltic Sea Region and its Symptoms Today, (eds.) Oliver Rathkolb, Imbi Sooman (Göttingen 2011), pp. 89-110.

${ }^{14}$ О. Малинова, Актуальное прошлое: Символическаяполитика властвующей элиты и дилеммы российской идентичности (Москва, 2015), pp. 122.

${ }^{15}$ Торбаков, “Непредсказуемое' или ‘неопределенное' прошлое?..., pp. 91-125, here: pp. 110-111. 
critical stance among many researchers; however, it did have quite an important secondary resonance. Even though the commission did not achieve much, it did cooperate a lot with institutions created to implement Russia's history policy, and initiated the publication of two source anthologies in 2009 dedicated to the foreign policy of Poland and the Baltic States before the outbreak of the Second World War. ${ }^{16}$ That same year, the Historical Perspectives Foundation, led by Narochinskaya, together with the Historical Memory Foundation, directed by Dyukov, extended the Polish issue, publishing a document anthology with the telling title Partitura Vtorii mirovoi. Kto i kogda nachal voinu? (Partiture for the Second World War. Who started the war, and when?). The answer to the question put in the anthology was somewhat unexpected. In the view of the anthology's editor, blame for the start of the Second World War also falls on Poland. The accusations made against Poland in 2009 were repeated in an article that was published on the website of the Russian Ministry of Defence, ${ }^{17}$ which only served to confirm the close links between these NGOs and the Kremlin. The general field of activity of all Russian institutions is evident from their publications. Most attention is focused on the Baltic States, Poland and Ukraine, seeking to expose figures from these states as collaborators with Hitler's Germany, and their governments as pro-German before the Second World War. Nor do the above-mentioned institutions avoid themes that would at first glance appear to be detrimental to Russia, such as the deportation of people from the Baltic States to Siberia. By revealing brutal events from the past in various publications on this theme, the authors seek to justify the actions by the Soviet government to isolate anti-Soviet elements. ${ }^{18}$

Poland started to participate in the information wars at a similar time, and for almost identical reasons. One fundamental difference from Russia should be noted at this point. Even though

\footnotetext{
${ }^{16}$ Прибалтика и геополитика. 1935-1945 г2., (ed.) Лев Соцков (Москва, 20о9); Секреты польской политики. Сборник документов (1935-1945), (ed.) Лев Соцков (Москва, 2009).

${ }^{17}$ On this and other Russian attacks against Poland, see: Biuro bezpieczenstwa narodowego, 'Propaganda historyczna Rosji w latach 2004-2009', http://www.bbn. gov.pl/download.php?s=1\&id=3068 (accessed: 2019-o9-30).

${ }^{18}$ For more detail on this, see: Becker, Mythos Stalin, pp. 74-81.
} 
this might be denied in Poland itself, the past has always been important to Poland's politicians and its intellectual elite. However, until the beginning of the 21st century, its efforts were directed towards normalising relations with its neighbours, and also with Israel, using assessments of the past as an important resource in international relations. However, on the eve of the 21st century, dissatisfaction within Poland started to develop concerning the chosen strategy. The first major anniversary of the collapse of the communist system served as an impulse for this dissatisfaction. Then, the ultimate symbol of the collapse of communism became the demolition of the Berlin Wall, and the merits of the Solidarity movement were basically forgotten. As a result, even then ideas had started to mature in Poland about a Polish history policy that actually started being realised a little after 2005, when the Kaczynski brothers came to power. The changes to Poland's economic and international situation also had an influence on the emergence of these ideas, as in Russia. Apart from economic factors, the fact that Poland became a member of Nato in 1999 and a member of the EU in 2004 also played an important role. On one hand, this allowed the Poles to exploit these important structures to spread their approach to the past, and on the other, in Poland itself dissatisfaction grew regarding how Poland was seen within these new structures. Unlike most new member states, it was not satisfied with playing the role of a younger brother.

Nonetheless, a direct impulse for Poland to start information wars on the past came in the form of two debates (2001) about the participation of Poles in the massacre of Jews in Jedwabne, and changes to the memory culture of the Germans, where the aim was to find a space in the German identity for Germans as victims of the Second World War, not just accentuating blame for the Holocaust. The information wars between Poland and Germany on this issue are known primarily as the debates over the establishment of a centre against the deportations. The idea to create this centre came about in 2000; however, the most heated discussions on the theme unfolded in 2003-2010. ${ }^{19}$

${ }^{19}$ The course of these discussions in Poland and Germany is presented in: M. Röger, Flucht, Vertreibung und Umsiedlung. Mediale Erinnerungen und Debatten in Deutschland und Polen seit 1989 (Marburg, 2011). 
The significance of these two discussions had a major impact on the information wars within Poland itself, and on relations with Germany. It can be said that during the debates over Jedwabne, two approaches towards the past crystallised in Poland: the first (the rightist view) accentuated Poland's heroism at the beginning of the war against Germany (Westerplatte), and spoke in favour of marginalising Poland's darker pages in history, while the other (the leftist and liberal view) favoured speaking about Westerplatte and Jedwabne. ${ }^{20}$ Incidentally, representatives of both camps stated clearly that the Germans' attempts to make their own victims a part of the German identity were unacceptable, and yet chose different strategies in their information wars with Germany. The rightists began to raise the question of German reparations, while their opponents suggested creating a Second World War museum in Gdansk. According to Pawel Machciewicz, the initiator of this concept, it was meant to be the 'most European' museum in all of Europe. ${ }^{21}$

In effect, the 'Jedwabne complex', or the fear that all the blame for the Holocaust would be heaped on to the Poles, prompted them to fight against the term 'Polish concentration camps'. The statutes of the National Memory Institute in Poland that were changed to avoid this term created enormous Polish-Israeli and Polish-US tensions, also affecting relations between Poland and Ukraine.

The triangle presented here, Russia-Poland-Germany, may explain the motives of other countries in the region to initiate and participate in information wars on the past: these are, first and foremost, the goal of entrenching their particular view of the past in the international arena; or in the case of Germany, to see a transformation of memory culture and identity.

It is no secret that by participating in information wars, Lithuania also seeks to entrench its own interpretations of the past. The exceptionality of Lithuania, like the other Baltic States, from other countries in the region is expressed in the fact that the very

${ }^{20}$ P. Machcewicz, 'I Westerplatte o Jedwabne', Spory o historię 200o-2011 (Krakow, 2012), pp. 167-172.

${ }^{21}$ M. Łuczewski, 'Kontrrewolucyjne pojęcie 'Polityka historyczna' w Polsce', Stan Rzeczy, 1(10) (2016), pp. 221-253. 
circumstances under which they became independent states meant that the Hitler-Stalin pact of 1939, for example, was from the very beginning a fundamental myth in these countries. ${ }^{22}$ Nonetheless, as in the case of other countries as well, the Baltic States became actively involved in information wars only at the start of the 21st century. A relative threshold year could be 2005 and the debates about whether the Baltic States' leaders would or would not go to the 9 May celebrations in Moscow.

It is clear that once the Baltic States became EU and Nato members, better opportunities to entrench their assessments of the past on a worldwide scale became available to them. The support of European and Nato structures was very visible. In 2009, ESBO passed a resolution in Vilnius that basically equated Nazi crimes to Stalinist crimes, while in 2017 a video clip shown on the Nato website about postwar partisans could even have prompted the Lithuanians to defend the memory of the infamous partisan leader Ramanauskas-Vanagas, albeit using rather brutal measures. ${ }^{23}$

The case of Poland illustrates very well that not only relations with external neighbours, but also domestic policy, has a major influence on international wars. The same situation was repeated to the letter in the case of Ukraine. What we have in mind is not just the accelerated spread of national myths about early Western Ukraine, based on narratives about the distribution of the OUN (Organisation of Ukrainian Nationalists) and the UPA (Ukrainian Insurgent Army) throughout the whole territory of Ukraine after 2014, but also the 'fascist' and 'banderovtsy' stereotypes used in Russia in its information war against Ukraine. Even though the origins of these stereotypes are obviously associated with Soviet propaganda, they came back in Russia's and Ukraine's wars somewhat later, after the Orange Revolution in Ukraine. Then Russia's media channels started informing the Russian population about

${ }^{22}$ See: B. Christophe, Staat versus Identität. Zur Konstruktion von 'Nation' und 'nationalem Interesse' in den lituaischen Transformationsdiskursen von 1987-1995 (Köln, 1997), pp. 104-121.

${ }^{23}$ A. Nikžentaitis, J. Tauber, 'Aufruhr um einen Partisanen. Eine litauische Erinnerungsdebatte', Osteuropa: Der Fall. Gefangen in Russland, Erinnerung in Litauen, Jg. 68, H. 6 (2018), pp. 83-91. 
the 'rebirth of fascism' in Ukraine; however, neither were these epithets avoided in Ukraine's domestic policy. In 2007, in Krasnodon in the Luhansk oblast, and in Luhansk itself, a museum opened and a monument was erected in honour of those who died at the hands of OUN and UPA fighters. ${ }^{24}$

It is worth noting that Europe-wide memory themes are used broadly in information wars, primarily the memory of the Holocaust. This memory figure is today an important part of Russia's information war against the Ukrainians; however, in earlier times, Russia had used it against the Baltic States as well.

The Holocaust issue in the Soviet Union, and later in Russia too, was never really a central focus, and neither was it presented in school textbooks. ${ }^{25}$ The Poklonnaja Gora Jewish synagogue, one of the central memorials dedicated to the Great Patriotic War, was built immediately after 1995, and yet this was not at the initiative of a state institution. The Holocaust started attracting attention precisely for the requirements of information wars. The year 2006 was probably the first time that the Lithuanian Jew-murderer card was drawn, when the Russian propaganda publisher Evropa published a document anthology called ,Lithuania's Tragedy'. Since then, the theme has been regularly recalled during commemorations of victory in the Great Patriotic War. It has also become very useful for Russia when seeking allies against the EU, which basically equated Stalinist crimes with the crimes of the Nazis. For this reason, in their response to the ESBO resolution passed in Vilnius in 2009, Medvedev and the Israeli leader Peres released a joint declaration about the combined Russian-Jewish struggle against fascism. ${ }^{26}$

However, it is not just events of the 2oth century that are their prime object, as the Russian-Ukrainian information wars continue

\footnotetext{
${ }^{24}$ Г. Касьянов, Past continuous: історична політика 1980- $x-2000-x$. Украӥна та сусіди (Київ, 2018), р. 251.

${ }^{25}$ И. Альтман, 'Мемориализация Холокоста в России: история, современность, перспективы', Память о войне бо лет спустя: Россия, Германия, Европа, (ред.) М. Габович (Москва, 2005), pp. 509-53о.

${ }^{26}$ Колеров, “Историческая политика' в современной России: поиск институтов и языка', p. 461.
} 
to show. In 2007 and 2008, President Yushchenko issued decrees ordering preparations for another two anniversaries: the 1659 Battle of Konotop, and the Battle of Poltava of 1708. In the first case, he was referring to the Cossack victory over the Russian army; and in the second, attention was drawn not so much to the battle itself, as the attempts of Ivan Mazepa to end the union with Peter I and form a coalition with Charles XII of Sweden. In his decrees, Yushchenko remained politically correct, and did not elaborate on who was actually defeated. Nonetheless, these acts were commented on in Russian state institutions as an attempt to rewrite their shared history. The importance of historical questions is also evident from President Yushchenko's visit to Moscow in February 2008. Even though during his meeting with Putin, discussions focused mainly on the issues of gas supplies, Nato, Ukraine's European integration, and the demilitarisation of the Kerch Peninsula, the leaders of both countries also found time to talk about historical questions. In his memoirs, Yushchenko writes that he recommended marking not just the Battle of Poltava, but also the Baturyn massacre. Putin also responded to this matter at a joint press conference, noting that issues from their shared past had also been discussed. Another anniversary commemorated in Ukraine also made it into the information spotlight of war. ${ }^{27}$

The anniversary of the birth of Mazepa was marked at a national level in Ukraine in 2009, when Yushchenko founded a new award, the Cross of Ivan Mazepa. A monument was to be erected in Poltava in his honour, and a street in central Kiev was named after him. The Russian Duma also joined in. It released a statement highlighting that the names of Peter I and others in his circle should not be forgotten, and neither would the treachery of Ivan Mazepa be overlooked, for which he was condemned by the Russian Old Believer Church. The Duma continues to be astounded at how Ukraine's leaders encourage following the examples of such figures, while simultaneously casting a shadow over their pride in the victory on the battlefield at Poltava. Chernomyrdin,

${ }^{27}$ В. Ющенко, Недержавні таємнищі: нотатки на берегах пам'яті (Харків, 2014), pp. 484-486. 
the Russian ambassador to Ukraine, made the best comment on this issue. In an interview with the newspaper Kommersant, he said: 'Imagine if we were to build a monument to Hitler on the site of the Battle of Stalingrad. How would that look? ${ }^{28}$

The story of conflicts between Ukraine and Russia over the distant past forces us to look back to similar disputes between Lithuania and Belarus over the past; first of all, the alleged Belarusian attempt to appropriate the history of the Grand Duchy of Lithuania (GDL). This topic has received significant coverage. The State Security Department drew attention to these issues in its 2014 activity report ( 26 pages in total), finding the chance to mention the Russian ambassador's attempts to diminish the significance of the 1514 Battle of Orsha. ${ }^{29}$ In late 2017, the Lithuanian minister of culture called the Belarusians' plans to stage the opera Vytautas in Vilnius as 'a demonstration of soft power and a provocation'. ${ }^{\circ}$ It could be added that, in the light of the potential threat to the Lithuanian historical identity, these claims by the minister have the backing of a number of Lithuanian historians.

However, is this narrative actually a part of the information wars between Belarus and Lithuania?

In order to answer this question, firstly we must identify who is trying to appropriate the history of the GDL in our neighbouring country. Researchers both in Belarus and in other countries talk about the different political elites there who make different assessments of the past. ${ }^{31}$ Only one group, supporters of the Belarusian nationalist or ethno-cultural model, consider the history of the GDL as their own, rejecting the Russian and Soviet periods of history

${ }^{28}$ Касьянов, Past continuous: історична політика 1980- $x$ - 20оо- $x$, с. 381.

${ }^{29}$ Lietuvos Respublikos Valstybès Saugumo Departamentas, 2014 m. veiklos ataskaita, (State Security Department of the Republic of Lithuania, 2014 Activity Report), https://www.vsd.lt/wp-content/uploads/2017/o3/Veiklos-ataskaita-2014.pdf (accessed: 2019-o9-30).

${ }^{30}$ I. Jačauskas, 'Baltarusiai Vilniuje rodys baletą „Vytautas“: L. Ruokytė-Jonsson perspèja dèl provokacijos', https://www.delfi.lt/news/daily/education/baltarusiaivilniuje-rodys-baleta-vytautas-l-ruokyte-jonsson-perspeja-del-provokacijos.d?id= 75663873 (accessed: 2019-o9-30).

${ }^{31} \mathrm{G}$. Ioffe, 'Długotrwałe poszukiwanie białoruskiej tożsamości', in: Tożsamości zbiorowe Białorusinów (ed.) Ryszard Radzik (Lublin, 2012), pp. 55-104; A. Kazakiević, 'Współczesna białoruska tożsamość historyczna', ibid., pp. 245-265. 
as being foreign. It is no secret that it is precisely this group that forms the opposition to the present Belarusian president; whereas the ruling faction has completely different concepts of the past. These should be discussed in the plural. The first great narrative being popularised in Belarus is dominated by the honouring of the Soviet past, and the accentuation of historical links between Belarus and Russia. Aleksandr Lukashenko himself, under the strong influence of pan-Slavic ideas, considers the Belarusian Soviet Socialist Republic to be the forerunner of the present-day Belarusian state. It is in this context that he and his supporters view the GDL. Considering themselves to be an outpost of the Slavic nations, defending their civilisation from the West, they claim that by belonging to the grand duchy, the Belarusian nation not only escaped the Mongol-Tartar yoke, but also preserved the Slavic nation's original (read best) traditions..$^{32}$ On the other hand, in the words of Lukashenko, Belarus was never a part of Western civilisation. It was incorporated into the Western world, but due to its Orthodox beliefs, it was never 'familiar' to Westerners. ${ }^{33}$ This rather unique approach to the GDL and the Polish-Lithuanian Commonwealth, without identifying with it or distancing from it, allowed for the formation of another, at first glance, strange relationship with the cultural heritage of these states, which can be seen in the second narrative applied by the current Belarusian regime. On one hand, the restoration of magnates' houses there is viewed as giving variety to the cultural landscape, with no guarantees as to the 'antiques' being used in the task. The Belarusian president himself agreed to be patron of the Mir architectural restoration project. The most important thing in this approach is making the heritage objects 'their own'. Not only is it the grand dukes that have become part of present-day Belarus' 'own' heritage, but also members of the Radziwill, Tyskiewicz and Tyzenhaus families. The public discourse has completely overlooked this fact. Meanwhile, the GDL, and figures that are important to Belarusians, are 'Be-

${ }^{32}$ W. Śleszyński, Historia $w$ stużbie polityki. Zmiany polityczne a konstruowanie przekazu historycznego na ziemiach białoruskich w XX i XXI wieku (Białystok, 2018), pp. $325-326$.

${ }^{33}$ Ibid., p. 329. 
larusianised', or put through the pan-Slavic theory filter. A good example of this kind of 'Belarusianisation' is the monument in honour of Algirdas erected in Vitebsk in 2014. In the opinion of some researchers, its unveiling when the war between Russia and Ukraine was already under way, and the growing concern among the Belarusian political elite over the survival of their own state, was meant to be a signal to Russia that in the Middle Ages, the Belarusians had an alternative programme for the unification of the eastern Slavic lands. ${ }^{34}$

The general understanding of the relationship with the past in public spaces is further complicated by the combination of elements from two dominant narratives. As a result, elements commemorating Kosciuszko or Mickiewicz can often be found in the same public spaces alongside those honouring Dzerzhinsky and Lenin. It is surely difficult to call this kind of relationship with the GDL's past an appropriation of Lithuania's history.

Based on what has been said, it can be concluded that information wars in the modern world have become an important part of the foreign and domestic policies of countries. On the other hand, a degree of competency is required for their proper understanding. By analysing the situation at least in the region discussed here, it becomes clear that even though much is being said about information wars, the question of using the past in these conflicts has still not received due attention.

\section{Conclusions}

1. The phenomenon of the use of the past in information wars can be explained as a fighting measure to entrench a given country's authority in the eyes of the global community. This need arose among states in this region on the collapse of the old world systems and with the creation of new political blocs.

2. Associations have been noticed between information wars where the past is used and the growth of a country's economic potential. For this reason, this tool is used in the foreign policy

${ }^{34}$ Ibid., p. 383 . 
of the region's states at varying levels of intensity, and did not all commence at the same time.

3. Almost all the countries in the region started using the past as an instrument of soft power en masse only in the 21st century. This instrument carries particular weight in Poland and Russia, being used less commonly in Lithuania and Ukraine, and hardly at all by Belarus.

4. The storylines of the past being used in information wars can be divided into two categories:

a) Global identities, whose symbols have become Holocaust and Gulag figures; and

b) Symbols associated with the memory cultures and identities of separate societies, such as the idea of Slavic unity (in Russian-Ukrainian relations) or the past of the GDL (in Lithuanian-Belarusian relations).

5. It is predicted that the use of the past in information wars will only intensify in the future, and as a result, a more solid education in expert skills is required to meet these challenges; this type of education is currently lacking in countries of this region.

Author Details

Alvydas Nikžentaitis is director of the Lithuanian Institute of History.

Address: Lithuanian Institute of History, 5 Kražių St, Vilnius LT-o11o8, Lithuania E-mail: alvydas.nikzentaitis@istorija.lt

\section{Bibliography}

BECKER, Anna . Mythos Stalin. Stalinismus und staatliche Geschichtspolitik im postsowjetischen Russland der Ära Putin (Berlin-Brandenburg, 2016).

BRÜGEMANN, Karsten. 'Denkmäler des Grolls. Estland und die Kriege des 20. Jahrhunderts', Osteuropa, 58, H. 6 (2008), S. 129-146.

CHRISTOPHE, Barbara. Staat versus Identität. Zur Konstruktion von „Nation' und „nationalem Interesse“ in den lituaischen Transformationsdiskursen von 1987-1995 (Köln, 1997).

ERLL, Astrid. Kollektives Gedächtnis und Erinnerungskulturen: Eine Einführung (Weimar, 2011). 
IOFFE, Grigory. 'Długotrwałe poszukiwanie białoruskiej tożsamości', in: Tożsamości zbiorowe Białorusinów, red. R. Radzik (Lublin, 2012), s. 55-104.

KAZAKIEVIĆ, Andrej. 'Współczesna białoruska tożsamość historyczna', in: Tożsamości zbiorowe Biatorusinów, red. R. Radzik (Lublin, 2012), s. $245^{-265}$.

ŁUCZEWSKI, Michał. 'Kontrrewoliucyjne pojęcie 'Polityka historyczna' w Polsce', Stan Rzeczy, 1(10) (2016), s. 221-253.

MACHCEWICZ, Paweł. 'I Westerplatte o Jedwabne', in: P. Machcewicz, Spory o historię 2000-2011 (Krakow 2012), s. 167-172.

MALIUKEVIČIUS, Nerijus. 'Ekspansijos iš Rytų apraraiškos Lietuvos informacinëje erdveje', in: Politologija, 2(42) (2006), pp. 62-81.

MALIUKEVIČIUS, Nerijus. Rusijos informacijos geopolitikos potencialas ir sklaida Lietuvoje (Vilnius, 2008).

MICHALEVA, Galina. 'Vergangenheitsbewältigung als Voraussetzung für die Modernisierung Russlands', Osteuropa, Jg. 59, H. 7-8 (2009), S. 47-58.

MISIŪNAS, Remigijus. Informaciniu kovu kryžkelèse:JAV lietuviu informacines kovos XIX a. pab. - $1922 \mathrm{~m}$. (Vilnius, 2004).

NIKŽENTAITIS, Alvydas, TAUBER, Joachim. 'Aufruhr um einen Partisanen. Eine litauische Erinnerungsdebatte', Osteuropa: Der Fall. Gefangen in Russland, Erinnerung in Litauen, Jg. 68, H. 6 (2018), S. 83-91.

ROUSSO, Henry. 'Dilemma eines europäischen Gedächtnisses', in: Zeithistorische Forschungen / Studies in Contemporary History, Online-Ausgabe, 1 (2004), H. 3.

RÖGER, Maren. Flucht, Vertreibung und Umsiedlung. Mediale Erinnerungen und Debatten in Deutschland und Polen seit 1989 (Marburg, 2011).

'Russland kämpft. Gesetz und Kommission gegen Geschichtsfälscher', Osteuropa, Jg. 59, H. 7-8 (2009), S. 273-276.

SAVUKYNAS, Virginijus. 'Informaciniai karai kultūros semiotikos požiūriu (taikinys - tapatumas)', Agora. Politiniu komunikaciju studijos, Nr. 2 (12), 2013, pp. 42-6o.

ŚLESZYŃSKI, Wojciech. Historia w stużbie polityki. Zmiany polityczne a konstruowanie przekazu historycznego na ziemiach biatoruskich $w X X i$ XXI wieku (Białystok, 2018).

SMOLAR, Aleksander. 'Geschichtspolitik in Polen', Transit, Bd. 35 (2008), S. 50-67.

WELLER, Christoph. 'Internationale Politik und Konstruktivismus. Ein Beipackzettel', WeltTrends, Nr. 41, Winter 2003/2004, S. 107-123.

ZUBKOVA, Elena. 'Sowjetische Vergangenheit der baltischen Staaten: Schwerpunkte und Kontroverse der kollektiven Erinnerung und Geschichtsschreibung', in: Geschichtspolitik im erweiterten Ostseeraum und ihre aktuellen Symptome - Historical Memory Culture in the Enlarged 
Baltic Sea Region and its Symptoms Today, ed. O. Rathkolb, I. Sooman (Göttingen 2011), S. 89-110.

АЛЬТМАН, Илья. 'Мемориализация Холокоста в России: история, современность, перспективы', in: Память о войне 6о лет спустя: Россия, Германия, Европа, ред. М. Габович (Москва, 2005), с. 5о9-53о.

КАСЬЯНОВ, Георгій. Past continuous: історична політика 1980- $x$ 20оо-х. Украӥна та сусіди (Київ, 2018).

КОЛЕРОВ, Modest. “Историческая политика' в современной России: поиск институтов и языка', Русский сборник. Исследования по истории России, т. 16 (2014), с. 441-48о.

КОПОСОВ, Николай. Память строгого режима. История и политика в России (Москва, 2о11).

МАЛИНОВА, Ольга. ктуальное прошлое: Символическая политика властвующей элить и дилеммы российской идентичности (Москва, 2015).

ПИХОЯ, Рудольф. Москва, Кремль, власть: Россия на изломе тысячелетий, 1985-2005. Две истории одной страны (Москва, 20о7).

Прибалтика и геополитика. 1935-1945 г2., ред. Л. Соцков (Москва, 2009).

Секреты польской политики. Сборник документов (1935-1945), ред. Л. Соцков (Москва, 2оо9).

ТОРБАКОВ, Игорь. “Непредсказуемое' или 'неопределенное' прошлое? Международные отношения и российская историческая политика', in: Символическая политика. Выпуск 1: Конструирование представлений о прошлом как властный ресурс, ред. О. Малинова, Вып. 1 (Москва, 2013), с. 91-125.

ЮЩЕНКО, Віктор. Недержавні таємнииі: нотатки на берегах пам'яті (Харків, 2о14). 


\section{PRAEITIES IৃVYKIŲ VIETA \\ TARPTAUTINIUOSE INFORMACINIUOSE KARUOSE}

Santrauka

\section{ALVYDAS NIKŽENTAITIS}

Straipsnyje analizuojamas klausimas, kokị vaidmenį informaciniuose karuose vaidina atminties kultūra. Remiantis Lietuvos, Rusijos, Ukrainos, Lenkijos ir Baltarusijos šalių pavyzdžiais, daromos išvados, kad praeities pasitelkimą informaciniuose karuose galima aiškinti ir kaip kovos priemonę siekiant įtvirtinti savo šalies autoritetą pasaulinės bendrijos akyse. Toks poreikis regiono valstybėms atsirado sugriuvus senosioms pasaulinėms sistemoms ir kuriantis naujiems politiniams blokams.

1. Atskleistos sąsajos tarp informacinių karų, kuriuose kaip įrankis pasitelkiama praeitis, ir šalies ekonominio potencialo augimo. Dèl šios priežasties šis įrankis regiono valstybių užsienio politikoje naudojamas ne vienodai intensyviai, o ir juo naudotis buvo pradèta ne vienu metu.

2. Beveik visos regiono šalys praeitị, kaip minkštosios galios įranki, pradejjo plačiai naudoti tik XXI a. Šis įrankis ypač didelę reikšmę turi Lenkijoje ir Rusijoje, rečiau naudojamas Lietuvoje ir Ukrainoje, jo beveik visiškai nenaudoja Baltarusijos valstybė.

3. Informaciniuose karuose naudojamus praeities siužetus galima suskirstyti i dvi kategorijas: (a) globalių tapatybių, kurių simboliais yra tapusios Holokausto ir GULAG'o figūros, ir (b) su atskirų visuomenių atminties kultūromis ir tapatybèmis susijusius simbolius, tokius kaip slavų vienybės idejja (Rusijos-Ukrainos santykiuose) ar LDK praeitis (Lietuvos-Baltarusijos santykiuose.

4. Prognozuotina, kad būsimuosiuose informaciniuose karuose praeitimi bus remiamasi vis plačiau. Dèl šios priežasties būtina stiprinti ekspertinių gebejjimų šioje srityje ugdymą, kuris šiuo metu regiono valstybėse yra per menkas. 